\title{
The ecclesial notion of 'family' versus authentic families today: Evaluation of the initial findings of the 2014 Synod of Catholic Bishops
}

\author{
Duncan, Graham ${ }^{1}$ \\ University of Pretoria \\ graham.duncan@up.ac.za \\ Urbaniak, Jakub ${ }^{2}$ \\ University of Pretoria \\ urbaniak@staugustine.ac.za
}

\begin{abstract}
The traditional institution of the family within Roman Catholic Christianity and Christianity in general is in an invidious position in contemporary society, partly because it lacks an agreed definition in a fluid global context. The church is an institution in which families subsist and which both needs and bolsters the family unit for its own existence and stability. However, all major churches seem to be stuck in outdated traditional modes of understanding which are exclusive and cause great distress to many who do not conform to them. The Roman Catholic Church has recently inaugurated a discussion of pastoral challenges currently facing family life. This is an attempt to evaluate critically its initial findings through deconstructing the traditional notion of family on which the Church teaching seems to rely.
\end{abstract}

Keywords

Family, law of graduality, pastoral challenges, Pope Francis, Synod of Bishops

The source of joys and trials, of deep affections and relations - at times wounded - the family is truly a 'school of humanity' (GS \$52), of which we are in great need. Despite the many signs of crisis in the institution of

1 University of Pretoria, Faculty of Theology, Department of Church History and Church Polity (Professor Emeritus).

2 Senior lecturer in theology at St Augustine's College and Researcher at the University of Pretoria 
the family in various contexts of the 'global village', the desire for family remains alive, especially among the young, and is at the root of the Church's need to proclaim tirelessly and with profound conviction the 'Gospel of the family' entrusted to her with the revelation of God's love in Jesus Christ (Relatio post disceptationem $2014 \$ 2$ ).

\section{Introduction}

As academic theologians we operate with an underlying principle that we have a responsibility to ask fundamental questions, to discern what are the deepest sources and the most far-reaching ramifications of phenomena or proposals under investigation, instead of dwelling on the surface of the problems. In this instance one of the immediate (and by no means easy) questions we face is: Could or should the Church redefine the family at the upcoming Synod of Bishops (2015) considering that the state of the family is 'in flux' (Pollitt 2015:1) as it 'has been beset by the many profound and rapid changes that have affected society and culture' (FC $1981 \S 1$; see also Egan 2014:8)? Jung (2014:126) affirms that marriage as an institution is undergoing a tremendous transformation. Even the Synod Fathers, in their 2014 Relatio Synodi, concluded that: 'Anthropological and cultural changes in our times influence all aspects of life and require an analytic and diversified approach’ ( $R S 2014 \$ 5$ ).

However, in line with the above principle, a more fundamental question that we, as theologians, have to pose to try to make the current discussion more meaningful would be: Does the traditional understanding of family, on which the current Church teaching seems to rely, help us as the Church, to better carry out God's mission in today's world?

As theologians coming from two different traditions - Reformed and Roman Catholic - in this paper we seek to evaluate critically the initial findings of the 2014 III Extraordinary General Assembly of the Synod of Bishops of the Roman Catholic Church [RCC] precisely in that context. In order to do that, we first summarise the developments that took place at last year's Synod regarding the understanding of 'family'. Second, we embark on deconstructing the traditional notion of family used by the RCC to render explicit its various inadequacies which increase the gap between this notion and what real families, in all their diversity, actually are and experience. Last, we point to the key aspects of the ecclesial discussion on 
family which need to be addressed for the 2015 Synod to be capable of listening and giving guidance to real families, and to all families. ${ }^{3}$

\section{The 2014 Synod on Family}

The Third Extraordinary General Assembly of the Synod of Bishops of the RCC took place from 5-19 October 2014. There is nothing extraordinary about the synod of bishops meeting; bishops of various denominations do this regularly. Yet, most churches do not even give a great deal of attention to the matter of family. In this context, this recent Synod of Catholic Bishops deserves special attention, as it has provided a great service in holding a special assembly to discuss the role of the family in contemporary society. Pope Francis indicated a change of mentality by opening up a new way of considering issues, e.g., married couples talking about married life in contrast to a traditional hierarchical model wherein celibate bishops instruct the laity. He allowed questions that have been closed for some time to be raised, e.g., cohabitation, and demonstrated a willingness to engage through a new collegial understanding of the church based on the quadrilateral exercise of reason, tradition, scripture and experience as opposed to the old centralised system. He demonstrated that 'there are areas of our human lives that do not fit into the categories that have been created' (Pollitt 2015:2).

The Synod represents the first of a two stage process of evaluating the current state of family life in the Church and in the world, and ways and means of improving it by building up its authenticity and integrity by being 'honest to God and ourselves' (Egan 2014:36) through openness and care. Such a culture 'is not a mere matter of academic knowledge but of a mode of participation in various social practices' (Rowland 2015:60-61); it is 'actively seeking the good of the Church and the will of God, a culture of life' (Egan 2014:36). The second stage will take place from October 4-25, 2015, and will

3 This paper has been written in the first half of 2015. The Fourteenth Ordinary General Assembly of the Synod of Bishops, popularly referred to as the Synod on the Family, took place from 4 to 25 October 2015 with the theme of 'The Vocation and Mission of the Family in the Church and in the Contemporary World'. On 8 April 2016, Amoris Laetitia (Latin: 'The Joy of Love'), a post-synodic apostolic exhortation by Pope Francis, was released. The argument offered in our study should be re-considered and the discussion continued in light of these important developments. 
have theme: 'The Vocation and Mission of the Family in the Church and Contemporary World', which as many point out, echoes the title of the ground-breaking Pastoral Constitution of Vatican II Gaudium et Spes.

The result of the Synod was an interim document, 'Pastoral Challenges to the Family in the Context of Evangelization', to be developed at the continuation Synod in October 2015. However, before the final Report was issued, the so called Relatio post disceptationem (2014), the much more controversial 'post-discussion report' had been presented by the General Rapporteur of the Assembly, Cardinal Péter Erdö, after the first week of the Synod. A number of significant shifts occurred between the two reports in question, which is indicative of great tensions within the Church itself. When Cardinal Erdö introduced the midterm report to the media, he stressed that Jesus looked at men and women with love, journeying with them patiently and with mercy. He spoke of how Jesus Christ incarnated in human vulnerability to identify with humans and heal (save) them. Jesus, he said, taught that marriage was indissoluble, but understood those who could not adhere to this ideal; hence, he acknowledged divorce (Mt 19:9). In similar contexts, the report refers to the "law of graduality'4 as a reflection of the way God reaches out to humanity and leads God's people forward step by step (Relatio post disceptationem $2014 \$ 13$; \$17; \$47; see also FC \$34). Regarding divorced and civilly remarried Catholics, the midterm report notes the need for further reflection on whether the sacramental fullness of marriage excludes the possibility of recognising positive elements even in its imperfect forms; for example, whether there are positive elements in 'irregular' marriages (Relatio post disceptationem $2014 \$ 18$ ). While the midterm report notes that the question of cohabitation might indicate commitment-phobia, characteristic of a Western culture in particular, it also pointed to the possibility that such a choice may be taken «while waiting for a secure existence> such as a steady job and income (\$38). The Synod Fathers agree that when a civil marriage is stable, shows deep affection and care for children, then the Church should work to accompany it toward sacramentality. In this context, the report speaks of the need for 〈courageous pastoral choices〉 ( $\$ 40)$ and «new pastoral paths〉 (\$40); it also

4 Some translations speak of the law of gradualness. 
calls for case-by-case discernment according to the law of graduality», particularly regarding access to the sacraments (\$36-\$49).

This important notion, 'the law of graduality' (Grabowski 2014), which appeared in the Relatio post disceptationem, promoted by figures such as Walter Kasper and Rodriguez Maradiaga, has been contested by the most conservative officials like Gerard Müller and Raymond Burke who considered it relativistic in character and leading to idea of the 'graduality of the law'; as a result, there is no reference to gradualism in the final Relatio Synodi (2014). What is more, while in the midterm report, references were made to the 'positive aspects of civil unions and cohabitation', to 'caring for wounded families' and to 'welcoming homosexual persons' in the second report terminology changes significantly: Instead of looking at the 'positive aspects of civil unions and cohabitation', the Synod Fathers focus exclusively on the 'pastoral care for couples civilly [and religiously] married or living together’ (Relatio Synodi $2014 \$ 41-43$ ), which is seen mainly in terms of leading them towards the fullness of sacramental marriage; 'caring for wounded families' - i.e., separated, divorced-remarried, singleparent families, etc. - is being replaced at one point by 'care for broken and fragile families' (\$23-28); and finally the notion of 'welcoming homosexual persons' disappears completely to be replaced with the 'pastoral attention towards persons with homosexual tendencies' (\$55-56), which entails no grounds for considering homosexual unions. The shift in question is most evident precisely with regard to the question of homosexuality. With regard to pastoral challenges in relation to homosexual persons, the Relatio post disceptationem affirmed that:

The question of homosexuality leads to a serious reflection on how to elaborate realistic paths of affective growth and human and evangelical maturity integrating the sexual dimension: it appears therefore as an important educative challenge (\$51).

But more significantly, the midterm report famously noted that 'homosexual persons have gifts and qualities to offer to the Christian community' (\$50). This bold statement was followed by the questions which pose the challenge to the pastoral practices of the Church:

Are we capable of welcoming these people, guaranteeing to them a fraternal space in our communities? Often they wish to encounter a 
Church that offers them a welcoming home. Are our communities capable of providing that, accepting and valuing their sexual orientation, without compromising Catholic doctrine on the family and matrimony? Without denying the moral problems connected to homosexual unions it has to be noted that there are cases in which mutual aid to the point of sacrifice constitutes a precious support in the life of the partners $(\$ 50 ; \S 52)$.

Those statements not only made headlines, but also caused major controversy among the cardinals. As a consequence and under the strong pressure from the conservative wing of the Synod, the Relatio Synodi states that 'There are absolutely no grounds for considering homosexual unions to be in any way similar or even remotely analogous to God's plan for marriage and family' (Relatio Synodi $2014 \$ 55$ ), a conclusion that seems to close any possibility of further dialogue. What can be considered even more problematic is the fact that the Synod Fathers seem to question homosexuality as such, as a biological fact, since the final report does not speak anymore of 'homosexual persons', but of 'persons with homosexual tendencies’ (\$55).

To make the picture even more complex and nuanced, suffice it to mention that in the latest Lineamenta, that is, the document written in preparation for the XIV General Assembly of the Synod of Bishops in October 2015, the expression 'wounded families' comes back (Lineamenta $2014 \$ 43-53$ ), whereas 'persons with homosexual tendencies' and their families are again referred to as being in need of special 'pastoral attention', but no positive aspects of homosexual relationships are mentioned (Lineamenta $2014 \$ 54$ $55)$.

The developments that took place at the Synod of Bishops in Rome in 2014 as well as those ahead of us, in October 2015, have to be contextualised properly. There is no urgency here, for the RCC traditionally plays the long game. No pope can undermine any of his predecessors so change has to appear as if there is gradual or little change. Hence, 'the law of graduality'. The synod was made up of bishops appointed predominantly by popes John Paul II and Benedict XVI so we should not expect a significant move to the 'left' in terms of theological opinion. The RCC cannot break with its magisterial tradition: it continues in it and often old ideas, carefully 
adapted and imperceptibly developed, are being simply wrapped in new formulations. References to Pope Paul VI's controversial Humanae vitae (Relatio Synodi $2014 \$ 18$; \$58) indicate continuity of tradition rather than change or development. In many ways it is a case of 'Tell me the old, old story' (Hankey 1927:823). So, any evaluation has to take into account what is feasible within the broader politics of the possible, preferably without becoming involved in Vatican or church politics in a narrow sense. On the one hand, it is only possible to view the outcome of this Synod through the 'lens of Catholic tradition'. On the other hand, it has to be acknowledged that what is possible has to be understood in the light of the eternal nature of the gospel which has to be enculturated in dynamic cultures. Generally what the recent Synod recommends with regard to family life is integral to Jesus' teaching and has been accepted for centuries. However, one of the Synod's failures has been to treat the family as static rather than dynamic (Egan 2014:36). To this traditional Catholic notion of family we now turn.

\section{Deconstructing the Catholic notion of 'family'}

\subsection{Functioning definitions and their limitations}

The definition of family commonly accepted in the RCC today is 'an intimate community of life and love bonded together for life by blood, marriage or adoption' ( $F C \$ 17)$ :

And since in God's plan it has been established as an 'intimate community of life and love', the family has the mission to become more and more what it is, that is to say, a community of life and love, in an effort that will find fulfilment, as will everything created and redeemed, in the Kingdom of God... with love as its point of departure and making constant reference to it, the recent Synod [1980] emphasised four general tasks for the family:

1. Forming a community of persons;

2. Serving life;

3. Participating in the development of society;

4. Sharing in the life and mission of the Church. 
None of the above is specifically based on a married relationship, though this is assumed in the document. One of the questions that must be faced today is whether marriage is vital to family or not?

A (surprisingly) inclusive definition of marriage has been included in the Vatican II's Pastoral Constitution on the Church in the Modern World, which speaks of marriage in terms of 'a partnership of life and love’ (GS \$48). However, one must not forget about the RCC's conservative position on the exclusively heterosexual model of marriage, which has been strikingly affirmed by the recent Synod (Relatio Synodi $2014 \$ 55-56$ ).

Yet, a more traditional definition of the family might be:

Roman Catholic teaching holds that the Christian family is a supernatural unit created by its origin in the sacrament of marriage, having as its primary end the procreation and nurture of children. Its constitutive elements are the complete freedom of choice of the spouses, and the permanency of their union which derives from its nature. From these premises Roman Catholics argue that the family is the fundamental condition for 'the physical, moral, social and economic existence of human society' (Waddams 1967:127).

This view is supported by Greenwell ${ }^{5}$ :

Every child born to a family is a gift and a benefit not only to his or her family, but also to the entire community into which he or she is born. The family is the temple where the flame of life is transmitted. It is a temple dedicated to the Lord of Life. The family is naturally ordered to serve what John Paul II has called the Gospel of life, the Evangelium vitae. Every birth ought to declare: Life is good news! (2012)

Sheen expresses a significant truth: Christian marriage involves more than two parties: one man and one woman. The third party - often forgotten in what Bishop Sheen calls the 'dis-God-ed' generation - is God (Sheen 1951; see also Greenwell 2012). The parties enter into the institution by an act

5 Andrew M Greenwell is an attorney licensed to practice law in Texas, practicing in Corpus Christi, Texas. He is married with three children. He maintains a blog entirely devoted to the natural law called Lex Christianorum. His views are representative of the conservative view of Catholicism. 
of self-donation which certainly requires free will; but they do not define the institution. The institution of marriage, like all of what is, is entirely dependent on God the Creator, the God who is the 'author of marriage' and who 'endowed it with various benefits and purposes' (Compendium No. 230).

\subsection{Broadly on the Catholic notion of family}

Greenwell (2012) affirms that, by its very nature, the family is tied into society and is therefore subject to the fluid laws of social life. Uniquely, the family is the fundamental cell where human life is transferred from generation to generation. Greenwell (2012) affirms:

The family is therefore an intensely spiritual society, even when not Christian, and the conjugal act that is at the heart of the marriage and which is its fire has a spiritual dimension which is too often forgotten in our day. 'Fatherhood and motherhood represent a responsibility which is not simply physical but spiritual in nature.' Through motherhood and fatherhood 'there passes the genealogy of the person, which has its beginning in God and which must lead back to him’ (Compendium No. 237; quoting GS \$10).

He continues to reaffirm the traditional idea of family based on parental grounds:

The family contributes to the social good in an eminent fashion through responsible motherhood and fatherhood, the spouses' special participation in God's work of creation' (Compendium No. 232). For this reason, civil society, including the State is obliged to assure that its customs and laws support it because it is the historical and traditional unit on which society is built and it is a time honoured pragmatic basis on which to continue. Most fundamentally, neither the State nor civil society may impinge or in any manner 'violate the right to life, from conception to natural death.' Rather, the civil society and the State are obliged to 'protect and promote it' (Compendium No. 231).

This seems to indicate that marriage is solely for the production and nurture of children. However, it takes no account of the humanity of those involved as maturing persons in society and in their own right as well as their right 
to experience 'life, and may have it in all its fullness' (John 10:10). This is also linked to the right to freedom of choice. If this were to be the case, humans would be as well to die once their reproductive lives are over. Yet, Greenwell (2012) seems to acknowledge:

Granted, motherhood and fatherhood are not exercised in a vacuum. In making their decisions, couples are entitled to consider the 'physical, economic, psychological, and social conditions' which they confront. These present the setting in which responsible parenthood is practiced.

Greenwell (2012) further argues that modern technology has invaded the temple of the family in a negative manner which separates the procreative act from the unitive act and seeks to replace or substitute the conjugal act. The result is that 'the child comes about more as the result of an act of technology than as the natural fruit of a human act in which there is a full and total giving of the couple' (Compendium No. 235). In this view, children can be reduced from persons to commodities, the product of technology, and not the product of a physical, spiritual and moral selfgiving. The techniques that are available are many, including the donation of sperm or ova, surrogate motherhood, homologous and heterologous artificial fertilisation, etc. According to the Catholic teaching, while there are some techniques that deny assistance to the conjugal act or to the attainment of its effects which are legitimate, there are many illicit techniques that ought to be rejected. Ethically, the ends do not justify the means. This is a fundamental moral principle that tends to be forgotten in our day (Greenwell 2012). ${ }^{6}$

Furthermore, the RCC claims that children have rights to be born and raised within the confines of a 'natural family': 'The unborn child must be guaranteed the best possible conditions of existence through the stability of a family founded on marriage, through the complementarities of the two persons, father and mother' (Compendium No. 235). Thus, Greenwell (2012) concludes, any efforts to provide children to persons involved in

6 In this context, Greenwell (2012) laments: 'The immoral techniques that are available are unfortunately legion'. However, one could that there can be no such thing as techniques which are immoral, only immoral people employing them. All 'techniques' have potential for good use and bad. 
some sort of civil union other than a family founded on the marriage of one man and one woman are to be shunned as unnatural and violating the children's rights. And yet he himself opens the door to a questioning of the definition of family by arbitrarily qualifying a nuclear family as 'natural'. What is really a 'natural family'? Perhaps one where love is evident and active? While this is an essential quality or value, it can hardly be seen as definitive. Commitment and responsibility are also vital here. But again, these are qualities or values which do not seem to sufficiently narrow down and delineate the notion of family.

\subsection{Contextualisation - an African scenario}

Pollitt (2015:3) argues that any definition of the 'family' will depend on this institution being adequately contextualised. Social scientists now suggest that we can no longer define the family as we did in the $19^{\text {th }}$ century. For example, Cambridge professor Göran Therborn (2004) notes that in the $20^{\text {th }}$ century there have been a number of shifts in our understanding of family. Whether we could ever have defined the 'nuclear' family in Africa is a topic on its own. This is a very Western model of family and yet the model that the Christian Church has adopted. By doing so it has failed to take into account the views and experiences of Africa, Asia and Middle Eastern cultures (Pollitt 2015:3).

In terms of democracy, Pollitt argues:

Democracy has for the most part undermined the idea of patriarchal families and promoted the equality of men and women. A culture of human rights, which is very much part of the democratic ideology, has challenged the idea that women and children are property (Pollitt 2015:5).

Capitalism also has a major impact on the shape of family. In the Southern African context, the economic system continues to cause an immeasurable movement of people in the pursuit of a better life for them and their families. For instance, the father working in the mines in the North West, the mother as a domestic in Johannesburg and the children living with grandparents (normally grandmothers) in the Eastern Cape - such a situation has become something common for black South African families. As Pollitt concludes, 'economic migration has undeniably changed the 
essence of life in South Africa' and has had 'a huge effect on the family life' in particular (2015:5).

Thus in the South African context, the historical impact of apartheid and its aftermath still impact on family life (Marks \& Andersson 1990:32-37). Murray's (1987:242-243) somewhat dated comment is still relevant sadly:

Large numbers of men spend long periods at work leaving their women and children at home [which] generates economic insecurity, marital disharmony, marital and emotional misery, and problems relating to sexual morality and legitimacy, irrespective of then cultural definition of these matters.

\subsection{Issues of gender and sexual orientation}

Then, there are a number of issues concerning gender and sexual orientation where great developments have taken place in recent years in both natural and human sciences. Pollitt (2015:5) notes that according to many scientists, there are bio-physical/chemical differences between homosexuals and heterosexuals which have to be accounted for. These studies include research on Chromosome linkage, Epigenetics, Birth Order, Female Fertility, Pheromone, Brain Structure, Sexually dimorphic nuclei in the anterior hypothalamus, etc. Furthermore, today most psychologists in the behavioural and social sciences and the health and mental health professions globally view homosexuality as a healthy variation of human sexual orientation (American Psychological Association 2009). Had they been given the attention they deserve, the Catholic understanding of sexual orientation would be much less exclusive, reductionist and discriminatory. In fact, science is still often treated like the enemy, even though according to the official position of the Church it is meant to inform theological content and vice versa (GS \$57, \$62; FR ‘Opening Blessing’, \$106). In the teaching of the Church today, those who have been traditionally defined as 'deviants' (e.g., gays and transsexuals) are, at least, acknowledged as the members of families, but they are still not affirmed as constituting families by the Synod (Relatio Synodi $2014 \$ 55-56$ ). 


\subsection{Deconstruction proper: The normality of dysfunctionality}

However, the definition of marriage, which has functioned in the Catholic Church since Vatican II, namely 'a community of life and love', is much more inclusive and open-ended than what the above summary of the Catholic understanding of family might suggest.

The intimate partnership of married life and love... [have] a very important bearing on the continuation of the human race, on the personal development and eternal destiny of every member of the family, on the dignity, stability, peace and prosperity of the family and the whole human race... As a mutual gift of two persons, this intimate union and the good of the children impose total fidelity on the spouses and argue for an unbreakable oneness between them (GS $\$ 48$ ).

This conciliar take on marriage seems to indicate an interesting direction for developing a much needed imaginative and terminological framework for deconstructing the traditional Catholic concept of family.

The notions of community (or covenant), life and love are rooted in the biblical narrative more deeply than the term 'family'. In the Hebrew Bible, 'whenever the Hebrew wishes to define a community, he speaks of a family' (Grayston 1957:77). This idea is derived from the OT and ancient near eastern patriarchal dominance (Waddams 1967:127). In the NT we read things like Paul's 'household codes' which are not altogether clear. Sometimes they seem to advocate mutual love and respect; other times they are a little less loving and respectful in their instruction (Waddams 1967:127). Further, Egan (2014:9) reminds us that the basis on which the family of the New Testament was built was that of the pagan Roman family. Hence, it is possible that this concept and practice of family was inadvertently incorporated into Christian belief and practice.

In the New Testament, Jesus enhanced the position of women. This was to have significant effects on the life of the family, and developments are still in process as we can see in the intervening period until the present. There has been an evolving understanding of the family. In the OT we hear accounts of polygamy, extended families, arranged marriages and what sometimes looks like nuclear family. What Jesus said about family is also, at best, ambiguous; sometimes he is quite dismissive and surprisingly so (see Mk 3:31-35; Mt 12:46-50; Lk 8:19-21; Mt 10:35-36; Lk 14:26). Even 
his own family situation was unclear compared with the idealistic picture often presented by the Church:

The Holy Family of Nazareth is a wondrous model in whose school we 'understand why we have to maintain spiritual discipline, if we wish to follow the teachings of the Gospel and become Christ's disciples' (Relatio Synodi $2014 \$ 23$; the quote taken from Paul VI, Address at Nazareth, 5 January 1964).

But who actually did constitute Jesus' family? Was it one family or an amalgam of families? Where did all the children come from and who was the father[s] since there were at least seven children? Did Mary remarry after Joseph's death? This indicates the natural messiness of ancient and postmodern family life and (perhaps) what one could call a normality of dysfunctionality in stability.

The Catholic theology of marriage and family life has developed over a number of years, and there have been substantial changes within it before. For example, Natural Family Planning [NFP], which today is commonly considered as an approach approved and promoted by the RCC, has been accepted by the Church only quite recently. In Casti Connubi, a 1930 encyclical by Pope Pius XI, any attempt to block conception was still deemed gravely sinful (\$56). Gaudium et spes was written in very inclusive terms compared with the 2014 Synod's report; it refers constantly, but not exclusively, to 'partners' and 'spouses' (GS \$48-49). In this it can be seen as a missionary document prefiguring the emerging issues in later decades. The family is truly the 'school of humanity' (GS \$52); the desire to marry and form a family remains vibrant. It assumes this is of male and female, but is not overtly pre- or proscriptive.

In the postmodern context the definition of 'family' may vary considerably. For instance, in a discussion of cohabitation the question has to be asked: Can this be understood as a family or is it a family-in-waiting; and for how long does it remain so, if the cohabitation persists for a lengthy period or for life?

Married couples have dropped below half of all American households. Traditional forms of the family system are under serious threat from contemporary alternatives. Only a fifth of households follow traditional ways of having married couples raising a family together (Tavernise 2011). 
And yet who are we to say that those are not families? In the western world, marriages are no longer 'arranged' for economic, social or political gain (as was the case in certain biblical times), and children are no longer expected to contribute to family maintenance through financial and other forms. Instead, people choose partners based mainly on a romantic concept of love. This increased role of love indicates a societal shift toward favouring emotional fulfilment and relationships within a family, and this shift necessarily weakens the institution of the family, even when the RCC definition of family includes life (of necessity) and love (Coontz 2005). ${ }^{7}$

\section{Towards the 2015 Synod, with real families at heart}

\subsection{Addressing adequately the question of wounded families: Two examples of positive episcopal voices from Africa}

Archbishop Charles Palmer-Buckle of Accra, Ghana, suggests that the 2015 Synod might consider how 'the power of the keys' (Mt 16:19) could be employed to 'unbind' those who have divorced and civilly remarried without a decree of annulment. He characterises his thinking on this subject as 'daring' ('It is daring to say what I am saying', Palmer-Buckle \& Montagna 2015), while pointing to numerous examples of Jesus extending mercy to society's outcasts.

Bishop Jean-Paul Vesco (Oran, Algeria), in turn, speaks against the scandal of calling the faithful second marriage 'adultery' or remaining in a 'state of sin' (Vesco 2014):

I firmly believe that it is theologically possible to assert the indissolubility of real conjugal love and the uniqueness of sacramental marriage, and at the same time the possibility of pardon in the event that lifelong marriage one of life's most beautiful but perilous adventures - fails (Vesco 2014).

7 Margaret Mead considered the family as a main safeguard to continuing human progress. Observing, 'Human beings have learned, laboriously, to be human', she adds: 'We hold our present form of humanity on trust, [and] it is possible to lose it... It is not without significance that the most successful large-scale abrogations of the family have occurred not among simple savages (sic), living close to the subsistence edge, but among great nations and strong empires, the resources of which were ample, the populations huge, and the power almost unlimited' (Mead 1949:193-194). 


\subsection{Addressing adequately the question of homosexual people}

In the report, the Synod Fathers reaffirm that same-sex unions cannot be considered equal to matrimony. So what are they and is that a major problem? Clearly it is. Yet, 'every sign of unjust discrimination in their regard should be avoided’ (CDF $2003 \$ 4$; RS $2014 \$ 55$ ). This contributes to the stigmatisation and discrimination that Rome has condemned; at best it is paradoxical; at worst, it is hypocritical. The RCC still operates out of the understanding of homosexual orientation as an «objective disorder», as something being «ordered toward an intrinsic moral evil», though not sinful unless acted upon (CDF $1986 \$ 3$ ). By contrast, homosexual sexual activity is viewed as a 'moral disorder' (CDF $1986 \$ 7$ ) and 'homosexual acts' as 'contrary to the natural law [as they] close the sexual act to the gift of life [and] do not proceed from a genuine affective and sexual complementarity' [CCC \$2357]. It seems clear that until and unless the language of 'disorder' is revised, the Church will be unable to develop an adequate approach to homosexual people, and to the LGBTI people in general.

By analogy, in scientific-medical terms, there are hardly any serious scholars today who would conceive of homosexuality as a disorder. But one must remember that this major shift in the scientific community occurred only towards the end of the last century. The World Health Organisation and the associations of British and American psychologists have removed homosexuality from their lists of mental disorders because this belief is unsupported by modern science (Stuart 1992:8). Without a parallel shift in a theological-moral position of the Church on homosexuality, an adequate framework for addressing pastoral questions regarding homosexual people is missing.

Needless to say, marriage as an institution is undergoing a tremendous transformation around the globe. In this regard, the Church seems to be a few steps behind the society. Jung (2014:126) observes that the only actual reason why the RCC cannot acknowledge the value of marriage equality is its conservative view on the nature of homosexuality.

It makes sense to judge the pedagogical power of marriage equality harmful if you believe homosexuality is disordered. Civil law has a pedagogical function. The approval of same-sex marriage will be socially transformative... When same-sex marriage is licensed, people will find it 
easier to live sexually authentic lives... While the church's 'worry' makes sense given its teachings on the (im)morality of homosexual acts, it begs the question of how to build a society that fosters the greater sexual integrity and authenticity called forth by its own teachings. Support for sexual authenticity through marriage will not harm children (Jung 2014: 128).

Jung (2014:129) reports on a comparative study carried out on 106 children of school age in various parts of the USA over an extended period. The report revealed that children raised by lesbian and gay couples have grown and developed normally, including with regard to their gender identity. By comparison, how do we define a family that rejects a family member due to being gay? Commenting on the issue of housing for 'discarded' gay youth Word (2014:21-22) refers to the matter of homeless homosexuals: 'Most of the gay youth we take in come from either extremely conservative religious backgrounds or terribly dysfunctional homes. Some have been on their own since the age of fifteen' (2014:21).

Jung (2014:132) argues that marriage equality should be promoted for the same reasons marriage in general is promoted.

It serves spouses, children, and other kin across generations, gay and straight alike. Additionally, it may serve the common good by reducing the stigma, shame, and crimes associated with heterosexism. Because we have these several good reasons to promote marriage equality and little reason to see its curtailment as 'necessary', the religious liberty of those who do not share this vision will not be unduly constrained. Further, because homosexual behaviour can be morally good and because same-sex marriage serves the commonweal, like the psalmist we are grateful that 'God sets the lonely in families' (Jung 2014:132-133).

Martin (2014:138) responds to Jung's argument by saying that 'both the church and society have the opportunity to participate in remaking marriage for the human fulfilment of gays, lesbians, bisexuals, and transgendered persons' as they seek inclusion, spiritual care and a desire to serve others. However, in this context the question seems to be: What constitutes an ethical marriage and ethical family, and who has the authority to define and determine these matters? Of course, the struggle to reflect upon and answer these questions will differ according to our traditions, polities, and notions of justice-making (Martin 2014:140). 
But the problem for many is how to remain in a church when a desire for acceptance is met with rejection: 'It is very difficult to remain part of a church where you are not supported for what you are and where your relationship is condemned' (Peck \& Conklin 2014:34).

There is a belief that there is a shortage of resources for gay Catholics who wish to remain faithful within the church. However, as Tushnet points out, 'there's so much hidden treasure in the church... We have a rich spirituality of celibacy, a beautiful theology of friendship, and a startling history...' (2014:29; see also Aelred of Rievaulx 2010).

Regarding the value of same-sex relationships, Johan Bonny (bishop of Antwerp, Belgium) (Bonny 2014; Kuruvilla 2014) adopts a position from 'mercy' towards 'recognition':

We have to look inside the church for a formal recognition of the kind of interpersonal relationship that is also present in many gay couples. The intrinsic values are more important to me than the institutional question. The Christian ethic is based on lasting relationships where exclusivity, loyalty, and care are central to each other (Bonny in Kuruvilla 2014).

\subsection{Addressing adequately the question of regional diversity (African case)}

Bishop Bonny (Kuruvilla 2014) links 'the growing gap between the moral teaching of the Church and the moral insights of the faithful' with the problem of the correct relationship between primacy and collegiality in the Catholic Church:

An ecclesiological question arose in the midst of an ethical issue surrounding marriage and family life... During the Second Vatican Council, the bishops endeavoured together with the pope to achieve as high a level of consensus as possible... A mere three years after the Council, however, little remained of this sort of collegiality when Humanae Vitae was published... The absence of a collegial foundation led immediately to tensions, conflicts and divisions that were never to be resolved... The bond between the collegiality of the bishops and the primacy of the bishop of Rome... must be restored and without delay... The Catholic Church is in urgent need of a 
new and steadier platform of collegial dialogue, particularly in the domain of marriage and family life (Bonny 2014).

At the same time, bishop Bonny is weary of a 'monolithic collegiality' that would not take into account regional diversity.

In the African context there is a tension between the consensus model/ style of leadership, which is an ideal to pursue and for which African cultures provide rich resources, and the prevailing practice of an autocratic leadership which does not acknowledge the role of the laity as those who are directly affected. Furthermore, as illustrated by the recent interventions of the South African hierarchs, and Cardinal Napier in particular (Greaves 2014), during the III Extraordinary General Assembly of the Synod of Bishops in the Vatican, African Catholic bishops are among the most conservative and 'Roman' in matters ecclesial.

Other peculiarly African issues intrude here. One is the historical African understanding of a family which is more likely to be extended rather than nuclear which is an inheritance from the West. A family consists, not only of the present generation but includes the ancestors and those as yet unborn. Greenwell comments: Human life continues to burn within families from generation to generation in a 'communion of generations' (2012). Another is the contemporary issue resulting from the HIV/AIDs crisis where many families are headed by children due to the death of parents and older family relatives. Commitment and responsibility from surviving family members are vital in such circumstances.

\subsection{Consultation: How the Synod debates and makes decisions?}

As underscored in the Catholic Scholars' Statement on Marriage and the Family (WICR 2013), signed by over 400 Catholic academics from all over the world, the teaching of the church on family, marriage and sexuality cannot serve the needs of the faithful unless the data of human experience is taken seriously in the formation of pastoral guidance. The 2014 and 2015 parish surveys show that the Catholic Church is not unaware of this challenge. However, adequate 'consultation with all of the faithful, representing a broad spectrum of experience and reflection, not to mention a considerable amount of expertise among those who are professionally trained' (WICR 2013) must still find its expression in the way in which 
the Synod allows for a real debate instead of an ecclesially correct (non) discourse.

\subsection{Probing the 'law of graduality' as the most profound theological challenge}

As indicated earlier, the notion of gradualism is usually promoted in moral theology by those who take a more liberal and progressive approach, and opposed by the conservatives. This could suggest that the authors of this paper should appeal to the law of graduality, together with the likes of cardinals Kasper and Maradiaga, to support their claims. And yet, in our view, the theological evaluation of this concept requires a more nuanced approach.

Traditionally, in Catholic moral theology, the law of graduality is identified with the recognition that people improve their relationship with God and grow in the virtues gradually, that conversion is not 'a magic, one-time transformation, but an ongoing process of healing, growth and change'. This law is well expressed by John Paul II in his definition of conversion:

Thus a dynamic process develops, one which advances gradually with the progressive integration of the gifts of God and the demands of His definitive and absolute love in the entire personal and social life of man. Therefore an educational growth process is necessary, in order that individual believers, families and peoples, even civilization itself, by beginning from what they have already received of the mystery of Christ, may patiently be led forward, arriving at a richer understanding and a fuller integration of this mystery in their lives $(F C \$ 9)$.

However, the traditional approach employing the 'law of graduality' indicates a process with little sense of urgency despite the serious pastoral issues facing families in the twenty-first century. This is not the approach found in scripture. God in the Hebrew Bible acted decisively in times of Israel's distress to bring peace and healing (Gen 15; Judg 11; 2 Kgs 5). It was not Jesus' approach either; his approach towards the sinners, who were in need of healing, was kairotic rather: 'Go; do not sin again' (Jn 8:11); 'Stand up, take your bed and go home' (Mk 2:11); 'Go, sell everything you have, and give to the poor, then come and follow me' (Mk 10:11). His imperatives were marked by a clear sense of immediacy for the saving (healing) of souls and bodies. 
The kairos was distinguished by kenosis, his self-sacrificing on the cross; e.g., he decisively turned his face towards Jerusalem (Mk 10:32-34).

This does not undermine various pastoral approaches which may be gradual, a 'one step forward two steps backward' process. In many cases, the law of graduality may well suit the historical response of the RCC to needed change, as, for instance, in the situation of family in Africa (as was also the case in the Old Testament) where marriage already takes place in stages through a gradual approach. However, this is not an either/or but rather a both/and situation for the Bible allows for both immediate and gradual responses depending on the situation. For instance, in applying this thinking to wounded families, certainly time is required for healing to take place and for trust to be renewed. However, when applying it to the dissonance between the Church's teaching and the conduct of Christians (like the one brought about by Humanae Vitae's regulation of contraception), then perhaps a kairotic moment for radical change or redefinition has arrived.

Perhaps an ecumenical perception may shed light on this process:

The response and tactic of the Roman Church as she confronts the convulsion and transformation of this cultural era is astonishingly subtle and multiform. She moves around it; not, to be sure, in order to leave it or repudiate it, but to enfold it by indirection. Out of her store of enormous practical wisdom she knows how to seduce with the symbolism of Grace the gathering discontents and spiritual malnutrition of the modern man [sic]. Her theology remains what for four hundred years it has been; but her theology is not the visible hand she holds out to the world. What she does hold out is the mighty fascination of her symbolic richness. She knows that logic follows being; and if entire areas of being can be meaningfully infused with overtones of Grace, purpose, love, and salvation her theology will have ample time to add the requisite calcium to the developing embryo (Sittler 2000:23).

This may be a harsh judgment, but it does go to the essence of gradualism. Yet, the principle of graduality may lead to the recognition of a kairotic moment with appropriate action. This necessitates replacing a static with a dynamic or fluid understanding of the family. Such a juxtaposition of approaches presents a major challenge for the 2015 Synod to face. 


\section{Conclusion}

Perhaps the resolution to the matter has been staring us in the face since Gaudium et spes (1965) which defined marriage as a 'partnership of life and love’ (GS §48). It is about community as a reflection of the Holy Trinity - a community, but of which gender? Theology (and thealogy) resonates with this discussion. The RCC may insist that marriage is about the union of a man and a woman, but this simply no longer defines the basis of a universal understanding of family. This could be the mental shift that is required - to expand the concept and practice of family. Life and love are fundamental to experienced family life as an ideal despite human shortcomings. But most families are not ideal all of the time. Egan (2014:35) refers to them as 'stable but dysfunctional', and they require more than this in a concrete sense. They need commitment and responsibility in good and bad times. They need forgiveness and reconciliation, faith and hope, justice and shalom. These are qualities of community. Different cultures have different expectations in this regard according to the ethos of each particular community. If the gospel needs to be enculturated in the contexts in which it is proclaimed, how much more so is this necessary for Vatican documents? 'A one size fits all' has never worked and cannot work in the global context of diversity. This seems to be a hallmark of the 'New Evangelisation' (Groggan \& Kim 2015), now in its sixth decade. Whether or not the Synod Fathers like it, traditional heterosexual marriage is no longer the foundation of many families, and they have to decide whether or not to accept this reality.

We could do worse than heed the counsel of Pope Francis:

In order to walk among contemporary challenges, the decisive condition is to maintain a fixed gaze on Jesus Christ, to pause in contemplation and in adoration of his Face... Indeed, every time we return to the source of the Christian experience, new paths and undreamed of possibilities open up (Francis $2014 \$ 12$ ).

\section{List of abbreviations}

CCC: Roman Catholic Church. 1997. Catechism of the Catholic Church. Vatican City: Libreria Editrice Vaticana. 
CDF 1986: Congregation for the Doctrine of the Faith. 1986. Letter to the Bishops of the Catholic Church on the Pastoral Care of Homosexual Persons. Vatican City: Libreria Editrice Vaticana.

CDF 2003: Congregation for the Doctrine of the Faith. 2003.

Considerations regarding Proposals to Give Legal Recognition to Unions between Homosexual Persons. Vatican City: Libreria Editrice Vaticana.

Compendium: Roman Catholic Church. 2005. Compendium of the Catechism of the Catholic Church. Vatican City: Libreria Editrice Vaticana.

FC: John Paul II. 1981. Familiaris consortio: Apostolic exhortation on the role of the Christian family in the modern world. Vatican City: Libreria Editrice Vaticana.

Francis 2014: Francis. 2014. 'Address during the meeting on the family' (4 October). Vatican City: Libreria Editrice Vaticana.

GS: John Paul II. 1994. Gratissimam sane: Letter to families. Vatican City: Libreria Editrice Vaticana.

GS: Vatican II. 1965. Gaudium et Spes: Pastoral Constitution on the Church in the Modern World. Vatican City: Libreria Editrice Vaticana.

HV: Paul VI. 1968. Humanae vitae: Encyclical letter on the regulation of birth. Vatican City: Libreria Editrice Vaticana.

Lineamenta 2014: Synod of Bishops, XIV Ordinary General Assembly. 2014. 'The vocation and mission of the family in the Church and contemporary world: Lineamenta'. Vatican City: Libreria Editrice Vaticana.

Relatio post disceptationem 2014: Erdő, P. (Cardinal, the Relator General). 2014. Relatio post disceptationem. Vatican City: Libreria Editrice Vaticana.

Relatio Synodi 2014: Synod of Bishops, III Extraordinary General Assembly. 2014. Relatio Synodi: 'Pastoral challenges to the family in the context of evangelization' (5-9 October 2014). Vatican City: Libreria Editrice Vaticana. 
WICR 2013: Wijngaards Institute for Catholic Research. 2013. 'Catholic Scholars' Statement on Marriage and the Family: In preparation for the Synods of 2014 and 2015'.

\section{References}

Aelred of Rievaulx 2010. Spiritual Friendship / De Spirituali Amicitiâ. Collegeville, Minnesota: Cistercian Publications (published by Liturgical Press).

American Psychological Association. 2009. Appropriate Therapeutic Responses to Sexual Orientation: A Report. [Online]. Washington. Available: http://www.apa.org/pi/lgbt/resources/therapeutic-response.pdf

Bonny, J (Bishop of Antwerp). 2014. 'Synod on the Family: Expectations of a Diocesan Bishop'. [Online]. Available: http://www. associationofcatholicpriests.ie/wp-content/uploads/2014/09/SYNODON-FAMILY-ENG.pdf [Accessed 17 February 2015].

Congregation for the Doctrine of the Faith 1986. Letter to the Bishops of the Catholic Church on the Pastoral Care of Homosexual Persons. [Online]. Vatican City: Libreria Editrice Vaticana. Available: http:// www.vatican.va/roman_curia/congregations/cfaith/documents/rc_con_cfaith_ doc_19861001_homosexual-persons_en.html [Accessed 17 February 2015].

Congregation for the Doctrine of the Faith 2003. Considerations regarding Proposals to Give Legal Recognition to Unions between Homosexual Persons. [Online]. Vatican City: Libreria Editrice Vaticana. Available: http://www.vatican.va/roman_curia/congregations/cfaith/documents/rc_con_cfaith_ doc_20030731_homosexual-unions_en.html [Accessed 17 February 2015].

Coontz, S 2005. Marriage, a history: How love conquered marriage. New York: Viking/Penguin Books.

Egan, A 2014. 'Marriage and family life: Looking towards the synod'. Trefoil 282: 7-9, 34-36.

Erdő, P (Cardinal, the Relator General). 2014. Relatio post disceptationem. [Online]. Vatican City: Libreria Editrice Vaticana. Available: http:// ncronline.org/news/vatican/relatio-post-disceptationem-2014-synod-bishops-family [Accessed 28 October 2014]. 
Francis 2014. 'Address during the meeting on the family' (4 October). [Online]. Vatican City: Libreria Editrice Vaticana. Available: https:// w2.vatican.va/content/francesco/en/speeches/2014/october/documents/papafrancesco_20141004_incontro-per-la-famiglia.html [Accessed 28 0ctober 2014].

Grabowski, JS 2014. 'The law of gradualism: A process toward God'. Our Sunday Visitor 29 October. [Online]. Available: https://www.osv.com/ OSVNewsweekly/Bylssue/Article/Tabld/735/ArtMID/13636/ArticleID/16312/The-law-ofgradualism-A-process-toward-God.aspx [Accessed on 28 April 2015].

Grayston, K 1957. 'Family', in Richardson, A (ed). A theological wordbook of the Bible, pp. 76-79. London: SCM.

Greaves, M 2014. 'Pope appoints Cardinal Napier as synod organiser'. [Online]. Catholic Herald 21 November. Available: http://www. catholicherald.co.uk/news/2014/11/21/pope-appoints-cardinal-napier-as-synodorganiser/ [Accessed 6 January 2015].

Greenwell, AM 2012. 'Catholic Social Teaching: The family, gift and sanctuary of life'. [Online]. Catholic Online 17 January. Available: http://www.catholic.org/news/hf/family/story.php?id=44434 [Accessed 6 January 2015].

Groggan, P \& Kim, K 2015. The new evangelization: Faith, people, content and practice. London, Bloomsbury T \& T Clark.

Hankey, AC 1927. 'Tell me the old, old story' (no. 837). The church hymnary with supplement. Revised Edition. London, OUP.

Hornbeck, JP (eds). More than a monologue: Sexual diversity and the Catholic Church, pp. 17-25. New York: Fordham University Press.

John Paul II 1981. Familiaris consortio: Apostolic exhortation on the role of the Christian family in the modern world. [Online]. Vatican City: Libreria Editrice Vaticana. Available: https://w2.vatican.va/content/john-paulii/en/apost_exhortations/documents/hf_jp-ii_exh_19811122_familiaris-consortio.html [Accessed 15 April 2015].

John Paul II 1994. Gratissimam sane: Letter to families. [Online]. Vatican City: Libreria Editrice Vaticana. Available: https://w2.vatican.va/content/ john-paul-ii/en/letters/1994/documents/hf_jp-ii_let_02021994_families.html [Accessed 15 April 2015]. 
Jung, PB 2014. 'God sets the lonely in families', in Firer Hinze, C \& Hornbeck, JP (eds). More than a monologue: Sexual diversity and the Catholic Church, pp. 115-133. New York: Fordham University Press.

Kuruvilla, C 2014. 'Belgian Catholic Bishop Calls for Recognition of Same-Sex Relationships'. [Online]. The Huffington Post: Religion 31 December. Available: http://www.huffingtonpost.com/2014/12/31/belgian-bishopgay-marriage-_n_6401560.html [Accessed 17 February 2015].

Marks, S \& Andersen, N 1990. 'The epideomiology and culture of violence', in Manganyi NC \& du Toit A (eds). Political violence and the struggle in South Africa, pp: 29-69. London: Macmillan.

Martin, JM 2014 'Response to Patricia Beattie Jung', in Firer Hinze, C \& Hornbeck, JP (eds). More than a monologue: Sexual diversity and the Catholic Church, pp. 134-140. New York: Fordham University Press.

Mead, M 1949. Male and female. New York: Harper Collins.

Murray, C 1987. 'Class, gender and the household: The development cycle in Southern Africa'. Development and Change 18(2): 235-249.

Palmer-Buckle, C \& Montagna, D 2015. 'African Archbishop Lays Down "Daring" Challenge for Synod on the Family: Archbishop Charles Palmer-Buckle considers new uses of St. Peter's "power of the keys"”. [Online]. Aleteia 25 February. Available: http://www.aleteia.org/en/ religion/article/african-archbishop-lays-down-daring-challenge-for-synod-on-thefamily-5848157384605696 [Accessed 28 February 2015].

Paul VI 1968. Humanae vitae: Encyclical letter on the regulation of birth. [Online]. Vatican City: Libreria Editrice Vaticana. Available: http:// www.vatican.va/holy_father/paul_vi/encyclicals/documents/hf_p-vi_enc_25071968_ humanae-vitae_en.html [Accessed 12 February 2015].

Peck, J \& Conklin, C 2014. 'Our thirty-three-year-long dream to marry', in Firer Hinze, C \& Hornbeck, JP (eds). More than a monologue: Sexual diversity and the Catholic Church, pp. 32-42. New York: Fordham University Press. 
Pius XI 1930. Casti connubi: Encyclical letter on Christian marriage. [Online]. Vatican City: Libreria Editrice Vaticana. Available: https:// w2.vatican.va/content/pius-xi/en/encyclicals/documents/hf_p-xi_enc_19301231_casticonnubii.html [Accessed 14 February 2015].

Pollitt, R 2015. 'Could, or should, the Church redefine the family at the upcoming Synod of Bishops?', 7 March, Rosebank, Johannesburg [unpublished lecture].

Pollitt, R 2014. 'Family synod - a defining moment for Francis' papacy?'. Trefoil 282: 41.

Roman Catholic Church. 1997. Catechism of the Catholic Church. [Online]. Vatican City: Libreria Editrice Vaticana. Available: http:// www.vatican.va/archive/ENG0015/_INDEX.HTM [Accessed 17 February 2015].

Roman Catholic Church. 2005. Compendium of the Catechism of the Catholic Church. [Online]. Vatican City: Libreria Editrice Vaticana. Available: http://www.vatican.va/archive/compendium_cce/documents/ archive_2005_compendium-ccc_en.html [Accessed 17 February 2015].

Rowland, T 2015. 'Christ, culture and the New Evangelization', in Groggan, P \& Kim, K. The new evangelization: Faith, people, content and practice, pp. 45-62. London: Bloomsbury T \& T Clark.

Sheen, FJ 1951. Three to get married. New York: Appleton-Century-Crofts.

Sittler J 2000. 'A theology for earth', in Bonma-Prediger, S \& Bakken P (ed), Evocations of grace: The writings of Joseph Sittler on ecology, theology and ethics (Grand Rapids, Eerdmans, 2000, 20-31.

Stuart, E 1992. Daring to speak in love's name. London: Hamish Hamilton.

Synod of Bishops, III Extraordinary General Assembly. 2014. Relatio Synodi: 'Pastoral challenges to the family in the context of evangelization' (5-9 October 2014). [Online]. Available: http://www. vatican.va/roman_curia/synod/documents/rc_synod_doc_20141018_relatio-synodifamilia_en.html [Accessed 30 December 2014]. 
Synod of Bishops, XIV Ordinary General Assembly. 2014. 'The vocation and mission of the family in the Church and contemporary world: Lineamenta'. [Online]. Vatican City: Libreria Editrice Vaticana. Available: http://www.vatican.va/roman_curia/synod/documents/rc_synod_ doc_20141209_lineamenta-xiv-assembly_en.html [Accessed 28 April 2015].

Tavernise, S. 2011. 'Married couples are no longer a majority, census finds'. The New York Times 26 May. [Online]. Available: http://www. nytimes.com/2011/05/26/us/26marry.html?_r=2\&\# [Accessed 8 January 2014].

Therborn, G. 2004. Between sex and power: Family in the world, 19002000. London: Routledge.

Tushnet, E 2014. 'O tell me the truth about love', in Firer Hinze, C \& Hornbeck, JP (eds). More than a monologue: Sexual diversity and the Catholic Church, pp. 26-31. New York: Fordham University Press.

Vatican II 1965. Gaudium et Spes: Pastoral Constitution on the Church in the Modern World. [Online]. Vatican City: Libreria Editrice Vaticana. Available: http://www.vatican.va/archive/hist_councils/ii_vatican_council/ documents/vat-ii_const_19651207_gaudium-et-spes_en.html [Accessed on 26 January 2015].

Vesco, J-P 2014. 'Bishop offers a solution on Catholic divorce and remarriage'. Global Pulse 28 September. [Online]. Available: http://www.globalpulsemagazine.com/news/bishop-offers-a-solution-on-catholicdivorce-and-remarriage/114 [Accessed 17 February 2015].

Waddams, H 1967. 'Family', in Macquarrie, J (ed). A dictionary of Christian ethics, pp. 126-128. London: SCM.

Wijngaards Institute for Catholic Research. 2013. 'Catholic Scholars' Statement on Marriage and the Family: In preparation for the Synods of 2014 and 2015'. [Online]. Available: http://www.wijngaardsinstitute.org/ statement/index.asp [Accessed 17 February 2015].

Word, D 2014. 'This Catholic mom: Our family outreach', in Firer Hinze, C \& Hornbeck, JP (eds). More than a monologue: Sexual diversity and the Catholic Church, pp. 17-25. New York: Fordham University Press. 